\title{
Pengaruh Penerbitan Obligasi Syariah Terhadap Return Saham (Studi Kasus Pada Perusahaan Yang Menerbitkan Obligasi Syariah dan Terdaftar Pada Bursa Efek Indonesia (BEI)
}

\author{
Mutia Dwiana \\ Universitas Bina Darma \\ Email: dwianatia@gmail.com
}

\begin{abstract}
This type of research is quantitative, this research is conducted on companies that issue Islamic bonds and are listed at the Bursa Efek Indonesia (BEI). The method used is the event study method to show whether there is an effect of the issuance of Islamic bonds on stock returns in the event period of the issuance of Islamic bonds (sukuk), with a length of observation time of 15 days before and 15 days after the issuance event. The population used is companies that issue Islamic bonds that are still circulating as of February 2020. The sample was determined by purposive sampling technique and a sample of 15 incidents of Islamic bond issuance was obtained from 8 companies. Then the data is processed using t-test and paried sample $t$ test. The results showed that there was a significant Average Abnormal Return around the Islamic bond issuance period, which means that the issuance of Islamic bonds (sukuk) had an effect on stock returns. And there is also a significant difference in stock returns between before and after the issuance of Islamic bonds.
\end{abstract}

Keywords: Islamic bonds (sukuk), stock returns, average abnormal returns, event study

\section{Pendahuluan}

Pada saat mengembangkan usahanya atau ketika melakukan ekspansi perusahaan kerapkali mengalami beberapa kendala. Salah satunya yaitu kendala pemenuhan kebutuhan dana. Dalam memenuhi pendanaan selain dari modal sendiri dan pinjaman bank, perusahaan juga dapat mencari tambahan dana melalui pasar modal dengan menerbitkan saham dan obligasi. pasar modal merupakan bagian penting yang dijadikan sebagai tolak ukur dalam kemajuan perekonomian sebuah negara. Tumbuh dan berkembang dengan baik sebuah pasar modal di suatu negara merupakan ciri dari negara industri maju maupun berkembang.

Instrumen investasi dipasar modal Indonesia tidak hanya inventasi konvensional, tetapi juga investasi berbasis syariah. Fatah, (2016) mengemukakan Konsep keuangan berbasis syariah saat ini sedang banyak bermunculan. Kehadiran produk syariah di pasar modal Indonesia juga membuka peluang berinvestasi bagi masyarakat yang meyakini bahwa produk investasi konvensional mengandung elemn - elemen yang diharamkan. Bentuk instrumen keuangan syariah salah satunya yang telah banyak diterbitkan baik oleh korporasi mapun negara ialah Obligasi Syariah (Sukuk).

Septianingtyas, (2012) berpendapat Penerbitan obligasi syariah sebagai opsi bagi perusahaan dalam memenuhi serta mencukupi kebutuhan dananya. Jika perusahaan menerbitkan obligasi syariah maka akan terjadi perubahan terhadap sturuktur modal dan juga akan meningkatkan hutang jangka panjang perusahaan. Penerbitan Obligasi Syariah ini menyatakan informasi yang akan ditanggapi dengan berbeda oleh para investor, tergantung dari mana investor memandang informasi penerbitan obligasi syariah tersebut, apakah dari sisi positif atau negatif. Jika investor memandang positif peristiwa penerbitan obligasi syariah, maka return saham perusahaan akan mengalami kenaikan seiring naiknya harga saham perusahaan.

Obligasi syariah (sukuk) setiap tahunnya mengalami peningkatan, sampai pada awal tahun 2020 sudah 
238 obligasi syariah (sukuk) ini diterbitkan dengan total nilai emisi sebesar Rp. 48.655,90 miliar dan jumlah sukuk outstanding mencapai 146 penerbitan dengan nilai outstanding Rp. 29.600,00 miliar. Peningktan penerbitan obligasi syariah ini menandakan bahwa instrumen investasi tersebut sudah banyak diminati oleh sebagai sumber penambahan modal.

Dengan adanya penerbitan obligasi syariah, maka pelaku pasar modal akan bereaksi pada saat dan setelah pengumuman penerbitan obligasi dipublikasikan. Return saham diasumsikan mengalami perubahan ketika ada informasi baru dan diserap oleh pasar. Apabila para investor menggunakan informasi pengumuman penerbitan obligasi syariah dalam kegiatannya, maka pengumuman tersebut akan memberikan dampak terhadap return saham. Rumusan masalah yang diajukan dalam penelitian ini adalah sebagai berikut: (1) Apakah ada pengaruh penerbitan obligasi syariah terhadap return saham? (2) Apakah ada perbedaan return saham pada waktu sebelum dan sesudah penerbitan obligasi syariah?.

\section{Tinjauan Literatur}

\subsection{Signalling Theory}

Connelly, et al (2011) Mengemukakan signalling theory adalah suatu teori yang digunakan untuk mengetahui perilaku dua pihak baik itu individu atau organisasi yang mempunyai peluang untuk mengakses suatu informasi. Dalam teori signalling seseorang yang dalam hal ini adalah investor akan menerima informasi baik itu positif maupun negatif dari adanya peristiwa yang terjadi pada suatu entitas. Kemudian investor akan membuat keputusan mengenai investasinya. Teori Signalling berfokus terutama pada memberikan informasi positif dalam upaya untuk menyampaikan atribut organisasi yang positif.

\subsection{Pasar Modal}

Dalam Undang - Undang No. 8 Tahun 1995 tentang pasar modal "Pasar modal adalah kegiatan yang bersangkutan dengan penawaran umum dan perdagangan efek, perusahaan yang berkaitan dengan efek diterbitkannya, serta lembaga dan profesi yang berkaitan dengan efek yang diterbitkannya, serta lembaga dan profesi yang berkaitan dengan efek."

\subsection{Obligasi Syariah}

Sesuai dengan Fatwa Dewan Syariah Nasional No. 32/DSN-MUI/IX/2002, "Obligasi syariah ialah surat berharga jangka panjang berdasarkan prinsip syariah yang dikeluarkan oleh emiten kepada pemegang obligasi syariah yang mewajibkan emiten untuk membayar pendapatan kepada pemegang obligasi sayriah berupa bagi hasil/fee/margin, serta membayar kembali dana obligasi pada saat jatuh tempo."

\subsection{Return Saham}

Return atau tingkat pengembalian adalah selisih antara jumlah yang diterima dengan jumlah yang diinvestasikan. Sari Dewi \& Vijaya, (2018) mengemukakan Return merupakan keuntungan yang diperoleh oleh perusahaan, individu dan institusi dari hasil kebijakan investasi yang dilakukannya. Anggraini, (2017) berpendapat Return saham merupakan keuntungan yang diperoleh pemegang saham karena menginvestasikan dananya, keuntungan tersebut dapat berupa deviden (yield) dan keuntungan dari selisih harga sahamsekarang dengan periode sebelum (capital gain). Return saham berbanding positif dengan resiko, itu berarti semakin tinggi tingkat resiko yang diterima oleh pemegang saham makan semakin besar pula return yang didapat, begitu pula dengan sebaliknya. Menurut Jogiyanto, (2016) Return saham dibedakan menjadi dua; pertama 
return realisasi ialah return yang telah terjadi, kedua return ekspektasi ialah reutrn yang diharapkan dimasa yang akan datang oleh investor.

\subsection{Abnormal Return}

Jogiyanto, (2016) mengemukakan return tak normal / abnormal return merupakan kelebihan dari return yang sesungguhnya terjadi terhadap return normal. Sedangkan menurut Husnan, (2015) Abnormal return adalah selisih antara tingkat keuntungan sebenarnya dengan tingkat keuntungan yang diharapkan. Tingkat keuntungan yang diharapkan dihasilkan dengan model tertentu.

\subsection{Event Study}

Tandelilin, (2017) mengemukakan event study adalah penelitian yang mengamati dampak dari pengumuman informasi terhadap harga sekuritas. Peneilitian event study umumnya berkaitan dengan seberapa cepat suatu informasi yang masuk ke pasar dapat tercermin pada harga saham. Secara lebih spesifik event study meneliti tanggapan pasar atas kandungan informasi dari suatu publikasi peristiwa atau pengumuman tertentu. Informasi yang diumumkan tersebut dapat berisikan berita baik (good news) atau berita buruk (bad news).

Sedangkan menurut Ahmad \& Rahim, (2013) Event study theory ialah bagaimana informasi yang berada dalam pengumuman penerbitan obligasi syariah (sukuk) dapat ditanggapi oleh investor. Baik itu respon positif atau negatif dengan ada atau tidaknya abnormal return saham disekitar tanggal penerbitan obligasi syariah (sukuk).

\subsection{Hipotesis}

H1 : Terdapat pengaruh Penerbitan obligasi syariah yang signifikan terhadap return saham.

H2: Terdapat perbedaan return saham yang signifikan pada waktu sebelum dan sesudah penerbitan obligasi syariah.

\section{Research Method}

\subsection{Populasi dan Sampel}

Fauzi, Dencik, \& Asiati (2019) mengemukakan populasi adalah sekelompok entitas yang memiliki sejumlah karakteristik yang sama yang menjadi sasaran penelitian. Elemen populasi adalah keseluruhan subyek yang akan diukur, yang merupakan unit yang diteliti untuk dipelajar dan lalu ditarik kesimpulannya. Ditentukan populasi nya penelitian ini ialah perusahaan - perusahaan yang menerbitkan obliasi syariah dan teraftar di BEI yang masih beredar per februari 2020 maka diperoleh sebanyak 144 peristiwa penerbitan obligasi syariah (sukuk). Setelah populasi ditentukan, langkah selanjutnya ialah menentukan sampel, menurut Fauzi, Basyith, \& Asiati, (2019) sampel adalah bagian atau elemen yang diambil dari populasi untuk mewakili populasi kemudian dilakukan analisis dan ditarik kesimpulan dari sampel tersebut dan simpulanya juga akan dapat diberlakukan untuk populasi. Sampel ditentukan dengan teknik purposive sampling dan diperoleh sampel sebanyak 15 peristiwa penerbitan obligasi syariah dari 8 perusahaan. Adapun 44 peristiwa penerbitan obligasi syariah yang tidak masuk kedalam kriteria sampel penelitian dikarenakan perusahaan yang menerbitkan obligasi syariah tidak terdaftar dalam Bursa Efek Indonesia (BEI) dan tidak tersedianya data yang dibutuhkan dalam penelitian, dan 
juga bagi peristiwa penerbitan yang bersamaaan waktunya hanya diperhitungkan 1 kali penerbitan

\subsection{Jenis dan Sumber Data}

Dalam penelitian ini jenis data yang digunakan ialah data kuantitatif. Data kuantitatif adalah data dalam bentuk angka yang menggambarkan besaran atau jumlah, dan data ini menggunakan skala pengukuran interval dan skala rasio. Dalam penelitian ini ialah data sekunder, data - data tersebut tidak peneliti kumpulkan sendiri melainkan menggunakan data - data yang sudah go public diperoleh melalui website resmi www.idx.co.id dan www.ojk.go.id yang telah dikumpulkan dan diolah oleh pihak lain. Data sekunder ini ialah data perusahaan yang menerbitkan obligasi syariah yang masih beredar per Februari 2020 dan terdaftar di Bursa Efek Indonesia, yang berupa jumlah penerbitan, nilai penerbitan, dan harga saham.

\subsection{Teknik Pengumpulan Data}

Teknik pengumpulan data yang digunakan dalam penelitian ini adalah studi dokumentasi. Metode dokumentasi ini digunakan penulis untuk mengabil data mengenai peristiwa penerbitan obligasi syariah serta data harga saham perusahaan, menggunakan data perusahaan yang sudah go public yang memuat data dan informasi yang dibutuhkan, yang telah dikumpulkan, dioleh dan disusun oleh pihak lain. Teknik yang digunakan untuk pengumpulan data dilakukan dengan mengunduh data pada situs web resmi Bursa Efek Indonesia (BEI) www.idx.co.id. Dan Otoritas Jasa Keuangan (OJK) www.ojk.go.id.

Selain itu penulis juga menggunakan sumber studi pustaka. Data studi pustaka, penulis mengumpulkan data dengan membaca buku - buku, membaca literatur yang berkaitan dengan objek penelitian, membaca catatan, jurnal penelitian terdahulu, buku paket, refrensi - refrensi, internet, dan sumber informasi lainnya yang berhubungan dengan penyusunan skripsi.

\subsection{Variabel Penelitian}

Variabel Penelitian Menurut Fauzi, Basyith, \& Antoni, (2018) adalah objek atau kegiatan yang memiliki variasi tertentu yang ditentukan oleh peneliti untuk diteliti yang nantinya akan ditarik suatu kesimpulan. Maka varibael dalam penelitian ini adalah :

Peristiwa penerbitan obligasi syariah dilihat menggunakan tanggal penerbitan obliasi syariah.

Return saham dalam penelitian ini di proksikan dengan Average Abnormal Return.

Jogiyanto, (2016) Rumus yang digunakan untuk menghitung abnormal return adalah sebagai berikut:

Menghitung return saham harian individual / return sesungguhnya / realisasi. Untuk mencari $\mathrm{R} i, \mathrm{t}$ dengan rumus:

$\mathrm{R}_{\mathrm{i}, \mathrm{t}}=\frac{\mathrm{Pi}, \mathrm{t}-\mathrm{Pi}, \mathrm{t}-1}{\mathrm{Pi}, \mathrm{t}-1}$

Keterangan :

$\mathrm{R}$ i,t : return sesungguhnya

$\mathrm{P}$ i,t : harga saham sekarang pada waktu peristiwa periode ke-t 
P i,t -1 : harga saham sebelum pada waktu peristiwa periode ke-t

Menghitung Return ekspektasi (expected return), ialah IHSG dengan rumus:

$$
\mathrm{E}[\mathrm{Ri}, \mathrm{t}]=\frac{I H S G \mathrm{t}-I H S G \mathrm{t}-1}{I H S G \mathrm{t}-1}
$$

Keterangan :

$\mathrm{E}[\mathrm{Ri}, \mathrm{t}]=$ return ekspektasi pasar yang terjadi pada periode ke- $\mathrm{t}$

IHSGt = indeks harga saham gabungan yang terjadi pada peristiwa ke-t

IHSGt-1 = indeks harga saham gabungan yang terjadi pada peristiwa ke t-1

Menghitung abnormal return pada periode estimasi. Abnormal return dengan menggunakan model sesuai pasar (market-adjusted model) diperoleh dengan rumus sebagai berikut:

$R T N \mathrm{i}, \mathrm{t}=\mathrm{Ri}, \mathrm{t}-\mathrm{E}[\mathrm{Ri}, \mathrm{t}]$

Keterangan :

$\mathrm{RTNi}, \mathrm{t}=$ return tidak normal (abnormal return) penerbitan ke-i pada peristiwa periode ke-t

$\mathrm{Ri}, \mathrm{t}=$ return realisasi penerbitan ke-i pada peristiwa periode ke-t

$\mathrm{E}[\mathrm{Ri}, \mathrm{t}]=$ return ekspektasi penerbitan ke-i pada peristiwa periode ke-t

Mencari rata - rata return tak normal (Average Abnormal Return) sampel penelitian pada hari ke-t selama periode waktu pengamatan, dengan mengunakan rumus sebagai berikut :

$$
\operatorname{RRTN}_{\mathrm{t}}=\frac{\sum_{i=1}^{k} R T N \mathrm{i}, \mathrm{t}}{\mathrm{k}}
$$

Keterangan :

$\mathrm{RRTNt}=$ rata rata return tak normal (average abnormal return) pada hari ke- $\mathrm{t}$

$\mathrm{RTNi}, \mathrm{t}=$ return tidak normal (abnormal return) penerbitan ke-i pada peristiwa periode ke-t

$\mathrm{K}=$ Jumlah sekuritas yang terpengaruh oleh peristiwa pengumuman

\subsection{Analisis Data}

Analisis data yang digunakan dalam penelitian ini ialah uji t-tes dan uji paired sampel $t$ test. 


\section{Hasil dan Pembahasan}

\subsection{Analisis Statistik Deskriptive}

Tabel 1. Hasil Uji Statistik Deskriptif

\begin{tabular}{|l|r|r|r|r|r|}
\hline & N & Minimum & Maximum & \multicolumn{1}{c|}{ Mean } & \multicolumn{1}{c|}{ Std. Deviation } \\
\hline AAR & 31 &,- 01419 &, 01253 &,- 0005804 &, 00680288 \\
Valid N (listwise) & 31 & & & & \\
\hline
\end{tabular}

Dari output SPSS 22 tabel diatas menggambarkan bahwa Average Abnormal Return yang digunakan dalam penelitian selama 31 hari periode pengamatan menunjukkan hasil bahwa nilai AAR minimum ialah $-0,01419$ terletak pada hari ke +4 setelah penerbitan obligasi syariah. Nilai maximum nya adalah 0,01253 terjadi pada hari ke -9 sebelum penerbitan obliasi syariah. Sedangkan nilai mean (rata - rata) ialah -0,0005804, dan nilai Std. Deviasi yang digunakan untuk mengetahui sebaran datanya menunjukkan angka sebesar 0,00680288 .

\subsection{Uji Normalitas Data}

Tabel 2. Hasil Uji Normalitas Data

\begin{tabular}{|ll|r|}
\hline \multicolumn{2}{|c|}{ One-Sample Kolmogorov-Smirnov Test } \\
\hline N & & \multicolumn{1}{|c|}{ AAR } \\
Normal Parameters ${ }^{\mathrm{a}, \mathrm{b}}$ & Mean & 31 \\
& Std. Deviation &, 00680288 \\
Most Extreme Differences & Absolute &, 091 \\
& Positive &, 091 \\
& Negative &,- 072 \\
& &, 091 \\
Test Statistic & &, $200^{c, d}$ \\
Asymp. Sig. (2-tailed) & &
\end{tabular}

a. Test distribution is Normal.

Seperti yang terlihat dari tabel 2 diatas bahwa Sig. (2-tailed) yang dihasilkan senilai 0,200 yang artinya bahwa nilai tersebut lebih besar dari $\alpha=5 \%$ yang ditetapkan, yaitu Sig.(2tailed) 0,200 $>\alpha=0,05$. Dari hasil tersebut dapat dikatakan bahwa data yang digunakan dalam penelitian berdistribusi normal.

\subsection{Uji t-test}


Tabel 3. Hasil Uji t-test

\begin{tabular}{|c|c|c|c|}
\hline Hari & AAR & KSE & t-hitung \\
\hline $\mathrm{H}-15$ & 0,001759 & 0,003862 & 0,455516 \\
\hline H-14 & $-0,00525$ & 0,038969 & $-0,13463$ \\
\hline $\mathrm{H}-13$ & 0,010633 & 0,021659 & 0,490937 \\
\hline $\mathrm{H}-12$ & $-0,00284$ & 0,008003 & $-0,35457$ \\
\hline $\mathrm{H}-11$ & $-0,00432$ & 0,004035 & $-1,07129$ \\
\hline $\mathrm{H}-10$ & $-0,00223$ & 0,005648 & $-0,3941$ \\
\hline $\mathrm{H}-9$ & 0,01253 & 0,019206 & 0,652375 \\
\hline H-8 & $-0,00333$ & 0,00307 & $-1,08593$ \\
\hline H-7 & 0,008447 & 0,022118 & 0,381925 \\
\hline H-6 & $-0,0114$ & 0,008107 & $-1,4064$ \\
\hline H-5 & 0,005428 & 0,001708 & 3,177181 \\
\hline $\mathrm{H}-4$ & 0,010168 & 0,041491 & 0,245066 \\
\hline $\mathrm{H}-3$ & 0,001725 & 0,020822 & 0,082847 \\
\hline $\mathrm{H}-2$ & 0,004924 & 0,010653 & 0,462184 \\
\hline $\mathrm{H}-1$ & 0,002694 & 0,003622 & 0,74388 \\
\hline $\mathrm{H}$ & $-0,00138$ & 0,004306 & 0,32068 \\
\hline $\mathrm{H}+1$ & $-0,00858$ & 0,005603 & 0,5307 \\
\hline $\mathrm{H}+2$ & $-0,00364$ & 0,004851 & $-0,75071$ \\
\hline $\mathrm{H}+3$ & $-0,003$ & 0,00085 & 2,12738 \\
\hline $\mathrm{H}+4$ & $-0,01419$ & 0,007308 & 0,94226 \\
\hline $\mathrm{H}+5$ & $-0,00764$ & 0,007833 & $-0,97476$ \\
\hline $\mathrm{H}+6$ & $-0,00079$ & 0,003276 & $-0,24165$ \\
\hline $\mathrm{H}+7$ & $-8,7 \mathrm{E}-05$ & 0,002564 & $-0,034$ \\
\hline $\mathrm{H}+8$ & $-0,00076$ & 0,003369 & $-0,22481$ \\
\hline $\mathrm{H}+9$ & $-0,00817$ & 0,002922 & $-1,79677$ \\
\hline $\mathrm{H}+10$ & $-0,00866$ & 0,00908 & $-0,95412$ \\
\hline $\mathrm{H}+11$ & 0,01144 & 0,017481 & 0,654425 \\
\hline $\mathrm{H}+12$ & $-0,0044$ & 0,008331 & $-0,5285$ \\
\hline $\mathrm{H}+13$ & $-0,00368$ & 0,002712 & $-1,35629$ \\
\hline $\mathrm{H}+14$ & 0,002808 & 0,019524 & 0,14382 \\
\hline $\mathrm{H}+15$ & 0,003801 & 0,016463 & 0,230871 \\
\hline
\end{tabular}


Keterangan :

*Signifikansi 5\% dengan nilai t-tabel 2,13145

Dari tabel 4.4 diatas menunjukkan hasil selama 31 hari periode pengamatan terdapat AAR yang signifikan pada hari ke-5 sebelum pengumuman penerbitan obligasi syariah. Hal ini ditunjungkan dengan nilai t- hitung 3,17718 > dari nilai t-tabel 2,13145 dengan tingkat signifikansi yaitu 5\%. Hasil ini menandakan bahwa terdapat AAR yang signifikan disekitar tanggal pengumuman penerbitan obligasi syariah. Yaitu pada hari ke-5 sebelum penerbitan obligasi syariah (H-5). Itu artinya menolak H0 dan menerima H1.

\subsection{Uji Paired Sampel t-test}

Tabel 4. Hasil Uji Paired Sampel t-test

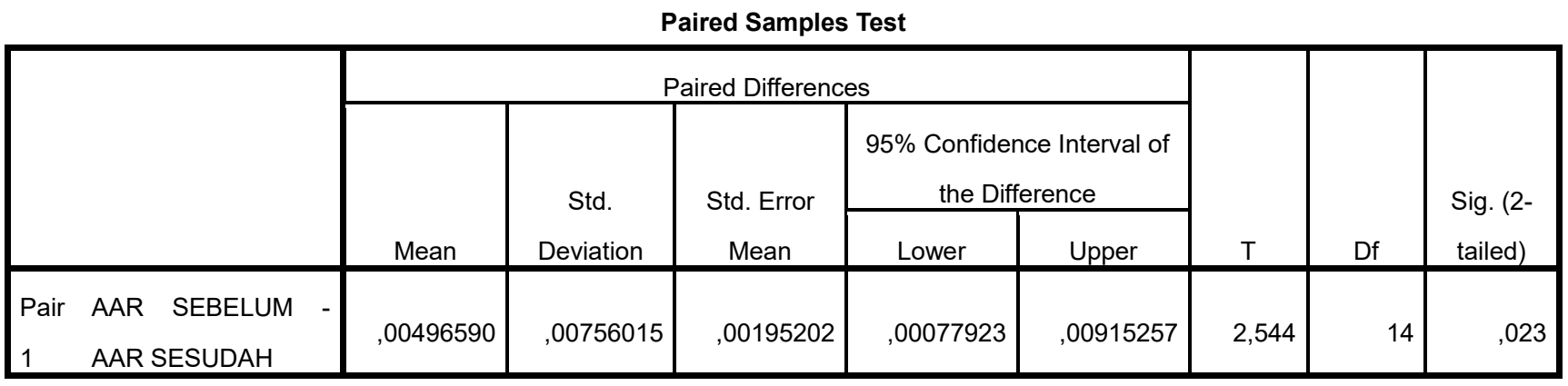

Pada tabel 4 diatas menunjukan nilai Sig. (2-tiled) sebesar 0,023 ini menyatakan nilai yang lebih kecil dari $\alpha$, atau $0,023<\alpha=0,05$ yang artinya bahwa $\mathrm{H} 2$ diterima dan menolak H0. Maka terdapat perbedaan Average Abnormal Return yang signifikan pada saat sebelum dan sesudah pengumuman penerbitan obligasi syariah.

\subsection{Pembahasan}

Setelah melakukan uji hipotesis t-tes dan paired sampel t-tes tahapan berikutnya akan dilakukan pembahasan lebih lanjut mengenai hasil pengujian tersebut :

\subsubsection{Pembahasan 1}

Hasil uji hipotesis yang telah dilakukan selama 31 hari periode pengamatan terdapat Average Abnormal Return (AAR) yang signifikan di sekitar tanggal pengumuman penerbitan obligasi syariah. Yaitu pada hari ke-5 (H-5) sebelum penerbitan obligasi syariah, itu menandakan menolak $\mathrm{H} 0$ dan menerima H1. Adanya AAR yang signifikan disekitar tanggal peristiwa penerbitan artinya bahwa penerbitan obligasi syariah berpengaruh terhadap return saham.

Dengan adanya AAR yang signifikan tersebut menunjukkan bahwa pengumuman penerbitan obligasi syariah (sukuk) mengandung informasi yang kemudian direspon oleh investor saham. Sehingga sinyal-sinyal berupa informasi yang muncul dari adanya penerbitan obligasi syariah (sukuk) dapat ditangkap oleh investor.

Selain itu selama 31 hari periode pengamatan terdapat respon yang positif pula dari para investor, yaitu terletak pada hari ke $-15,13,9,7,4,3,2,1$ sebelum penerbitan, pada hari 
saat hari - H penerbitan, dan juga pada hari ke $-1,3,4,11,14,15$ setelah penerbitan. Hal tersebut sesuai dengan yang diharapkan bahwa investor memberikan respon yang positif.

\subsubsection{Pembahasan 2}

Dalam penelitian ini dibuktikan dengan nilai Sig. (2-tiled) sebesar 0,023 ini menyatakan nilai yang lebih kecil dari $\alpha$ taraf signifikansi yang telah di tentukan $5 \%$, atau $0,023<\alpha$ $=0,05$. Itu artinya $\mathrm{H} 2$ diterima dan menolak H0. Dapat diartikan terdapat perbedaan return saham yang signifikan pada sebeulm dan sesudah penerbitan obligasi syariah. Hal tersebut berarti, secara kumulatif terjadi penuruanan dan kenaikan return saham yang signifikan selama periode pengamatan.

Adanya perbedaan abnormal return signifikan pada periode sebelum dan sesudah penerbitan obligasi syariah (sukuk) dapat diartikan bahwa penerbitan obligasi syariah (sukuk) membawa kandungan informasi yang bernilai tentang akan adanya perbedaan keuntungan di masa mendatang dan juga mengindikasikan bernilainya informasi penerbitan obligasi syariah tersebut bagi investor sebagai nilai yang positif, karena para investor memang menganggap bahwa penerbitan obligasi syariah (sukuk) akan menambah dana perusahaan yang kemudian akan digunakan untuk meningkatkan nilai perusahaan

\section{Kesimpulan}

Terdapat $A A R$ yang signifikan disekitar tanggal pengumuman penerbitan obligasi syariah, tepatnya pada hari ke-5 sebelum pengumuman penerbitan dengan nilai t-hitung 3,17718 > dari nilai t-tabel 2,13145 Itu artinya menolak H0 dan menerima H1. Dapat disimpulkan bahwa penerbitan obligasi syariah berpengaruh terhadap return saham. Dari hasil uji statistik paried sampel t tes diperoleh nilai Sig. (2-tiled) sebesar 0,023 ini menyatakan nilai yang lebih kecil dari $\alpha$ taraf signifikansi yang telah di tentukan $5 \%$, atau $0,023<\alpha$ $=0,05$. Itu artinya $\mathrm{H} 2$ diterima dan menolak H0. Maka disimpulkan terdapat perbedaan return saham yang signifikan pada sebeulm dan sesudah penerbitan obligasi syariah.

\section{Referensi}

Ahmad, N., \& Rahim, S. A. (2013). Invesgating stock market reactions on sukuk issuance based on rating. 4th. International Conference on Business and Economic Research (4th ICBER 2013) Proceeding.

Connelly, B. L., Certo, S. T., Ireland, R. D., \& Reutzel, C. R. (2011). Signalling theory: A review and assesment 37(1): 39-67. Journal of Manajement .

Fatah, D. A. (2016). Perkembangan Obligasi Syariah (sukuk) di Indonesia: Analisis Peluang dan Tantangan. Al-'Adalah Vol X, No.1.

Fauzi, F., Basyith, A., \& Antoni, D. (2018). Statistik. Palembang: PT Rajagrafindo Persada.

Fauzi, F., Basyith, A., \& Asiati, D. I. (2019). Metodelogi Penelitian Untuk Manajemen dan Akuntansi Aplikasi SPSS dan EViews untuk Teknik Analisis Data. Palembang: Selemba Empat.

Husnan, S. (2015). Dasar - Dasar Teori Portofolio dan Analisis Sekuritas . Yogyakarta: UPP STIM YKPN. 
Jogiyanto, H. (2016). Teori Portofolio dan Analisis Investasi. Edisi Kesepuluh. Yogyakarta : Penerbit BPFE.

Sari Dewi, G. K., \& Vijaya, D. P. (2018). Investasi Dan Pasar Modal Indonesia. Depok: Rajawali Pers.

Septianingtyas, D. A. (2012). Pengaruh Nilai dan Rating Penerbitan Obligasi Syariah (sukuk) Perusahaan Terhadap Return Saham (studi kasus pada perusahaan yang menerbitkan obligasi syariah dan terdaftar di BEI tahun 2002 - 2009). Skripsi yang di Publikasikan, Universitas Negeri Semarang.

Tandelilin, E. (2017). Pasar Modal : Manajemen Portofolio \& Investasi. Yogyakarta: PT Kanisius .

- $\underline{\text { www.idx.co.id }}$

- www.ojk.go.id

- Undang - Undang No. 8 Tahun 1995 tentang pasar modal.

- Fatwa Dewan Syariah Nasional Nomor 32/DSN-MUI/IX/2002.

\section{Copyrights}

Copyright for this article is retained by the author(s), with first publication rights granted to the journal.

This is an open-access article distributed under the terms and conditions of the Creative Commons Attribution license (http://creativecommons.org/licenses/by/4.0/) 